\title{
Research Station in the Galapagos
}

\section{BY D. W. SNOW}

Last July Dr. Snow returned to England after eighteen months in the Galapagos as director of the Charles Darwin Research Station. In this article he describes briefly the Station's main task in its first four years of getting established and the work that is now being done. The biggest threat at present to the native wildlife is the introduced goats, and the job of exterminating these on some of the islands has now been started.

U P to the time of its dedication on January 21st, 1964, reported in the April issue of ORYX, the Charles Darwin Research Station in the Galapagos Islands, though four years old, had been very much in the developmental stage. Nearly all the financial resources of the Charles Darwin Foundation, and much of the Station director's time, had been devoted to construction, the difficulties of which, in remote islands, on rugged terrain, with supplies irregularly available from the mainland 600 miles away, had been considerable. The dedication of the Station, followed by the Galapagos International Scientific Project, marked the end of this period of development, and shortly afterwards, on February 14th, the agreement between the Foundation and the Government of Ecuador was signed in Quito by the late Dr. Van Straelen, president of the Foundation, and representatives of Ecuador. This gave the Foundation important rights and privileges, as well as obligations towards Ecuador, and legalised its status in Ecuador. Another advance was made about a month later, when in response to a memorandum submitted by the Director of the Research Station the Government issued a special decree authorising the Research Station to take almost any steps it might deem necessary for the safeguarding of the Galapagos fauna and flora.

The Station's main buildings on low-lying ground on the east side of Academy Bay, about one kilometre from the settlement of Puerto Ayora, comprise a substantial laboratory of concrete-block construction, equipped with microscopes and other basic apparatus, and working space for some ten scientists ; a Director's house ; a building housing workshops and two diesel generators; a storage building; and a sixteen-bed dormitory block for visiting scientists.

A second-order meteorological station in a central part of the Station area is operated as part of the national meteorological service of Ecuador. The recently installed seismographic station is operated as part of the network of world-wide seismographic stations financed by the U.S. Coast and Geodetic Survey, the vault being situated about 700 metres inland from the main Station buildings, out of hearing of the surf and in a site where the underlying lava is solider than it is near the shore.

At the beginning of April, 1964, an important new addition was made to the Station's staff, reported in the August issue of ORYX, with the appointment as Conservation Officer of Sr. Miguel Castro, the most knowledgeable of the local naturalists and an ardent conservationist and 
tireless field worker. His salary for a period of three years was shortly afterwards assured by a grant from the New York Zoological Society. Thus by the beginning of May the Station was at last in a position to devote its resources primarily to its most important function, conservation. It was therefore most opportune that, on May 9th, the Beagle came safely to anchor in Academy Bay, and for the first time the Station was equipped with its own sea-going vessel.

No one with first-hand experience of the present condition of the Galapagos Islands can have any doubt that introduced animals constitute by far the most serious threat to the survival of the native fauna. Goats, pigs, cattle, donkeys, cats, and dogs have been introduced into one island or another; two islands at least have five out of the six. Of all these, goats have perhaps had the worst effect as they occur on the greatest number of islands, including some very dry islands where the native vegetation is quite unable to stand up to their constant browsing.

\section{Tortoises Gone, Iguanas Threatened}

Barrington is one such island. Its once thick vegetation has been reduced to a very open park-like woodland with the bush layer almost completely gone. At least two important plants, the wild cotton and wild tomato, have vanished. The native tortoise population became extinct long ago as a result of massive exploitation by the whalers, but the peculiar Barrington land iguana, usually regarded as an endemic species distinct from the land iguanas of the other islands, still survives in good numbers. Even so, continued degradation of the vegetation must inevitably reduce its numbers and, if unchecked, would probably lead to its extinction. In February this year a member of the Galapagos International Scientific Project spent some days on Barrington studying the goats and estimated that there were about 200: he found that many of them were emaciated and little breeding was taking place. For the last few years the wet seasons have almost failed in the Galapagos, and it seemed clear that the goat population had overeaten its food supply and was, temporarily at least, in decline. The time seemed ripe for a systematic attempt to eradicate the goats from Barrington.

At the beginning of June, Sr. Castro with four helpers spent four days on Barrington. In this time they killed 210 goats, and perhaps thirty to forty more. The survivors became so shy that further hunting then became unprofitable. Estimating that perhaps 50 to 100 still survived, Sr. Castro returned for several days in July: on this occasion about 300 more were killed! These visits are to be continued until Barrington is free of goats. Hood Island, whose state is as desperate as Barrington's, and Abingdon, where the goats have only recently been introduced, will be next on the list. This work, involving extra local labour, maintenance of camps in remote places, running of the Beagle, and other expenses, will involve considerable expense, as will the tortoise conservation programme outlined in the ensuing pages. The Station now has the staff and the equipment for the job. A start has been made. To ensure that the programme prospers, the continuing support of all those interested, governments, societies or private individuals, is more than ever essential. 